\title{
Selective Androgen Receptor Modulator LY2452473
}

National Cancer Institute

\section{Source}

National Cancer Institute. Selective Androgen Receptor Modulator LY2452473. NCI

Thesaurus. Code C123792.

An orally bioavailable selective androgen receptor modulator (SARM), with potential tissue-selective androgenic/anti-androg enic activity. Upon oral administration, LY2452473 acts as an agonist in select tissues and organs, including skeletal muscle, bone and the penis, thereby binding to and activating androg en receptor (AR) while acting as an antagonist in the prostate, thereby blocking AR activation and AR-mediated cellular proliferation. This may improve muscle mass and strength, bone formation, and erectile dysfunction while not stimulating growth of the prostate. 